DOI:10.22337/2587-9618-2019-15-3-40-54

\title{
“LAKHTA CENTER". MANAGEMENT CHALLENGES AND SOLUTIONS IN THE IMPLEMENTATION OF UNIQUE PROJECT DESIGNS
}

\author{
Elena A. Ilyukhina ${ }^{1}$, Alexey B. Miller ${ }^{2}$ \\ ${ }^{1}$ Joint Stock Company "Multifunctional complex Lakhta Center", Saint-Petersburg, RUSSIA \\ ${ }^{2}$ Public Joint Stock Company Gazprom, Saint-Petersburg, RUSSIA
}

\begin{abstract}
The "Lakhta Center" is the headquarters of public joint stock company "Gazprom", a key cultural and environmental project of Saint-Petersburg and the flagship object of the architectural, engineering and construction industries in Russia. The facility was completed for operating and became a precedent for the implementation of such a unique in scale and complexity project in Russia. It was realized on schedule and within the budget. The architectural dominant of the Lakhta Center is a tower with a height of 462 meters, which has become the tallest building in Europe. The following management challenges and solutions are under consideration in the distinctive paper: transfer of the object; land restrictions and related projects; the need to develop a regulatory documents; lack of relevant experience and competencies in Russia; building a flexible contracting system, separation of design and construction functions; a flexible approach to the preparation of project documentation, the main state expertise (Glavgosekspertiza) and the beginning of the zero cycle; building stages; package contracting system; managing by the global team; optimization of the project solutions; risk management system; global crisis; sanctions; changing the role of the customer / contractor during the project.
\end{abstract}

Keywords: high-rise building "Lakhta Center", building structures, management challenges and solutions, unique construction object

\section{«ЛАХТА ЦЕНТР». УПРАВЛЕНЧЕСКИЕ ВЫЗОВЫ И РЕШЕНИЯ ПРИ РЕАЛИЗАЦИИ КОНСТРУКЦИЙ УНИКАЛЬНОГО ПРОЕКТА}

\author{
Е.А. Илюхина ${ }^{1}$, А.Б. Миллер ${ }^{2}$ \\ ${ }^{1} \mathrm{AO}$ «Многофункциональный комплекс Лахта Центр», г. Санкт-Петербург, РОССИЯ \\ ${ }^{2}$ ПАО «Газпром», г. Москва, РОССИЯ
}

\begin{abstract}
Аннотация: «Лахта Центр» - штаб-квартира ПАО «Газпром», ключевой культурно-средовой проект Санкт-Петербурга и флагманский объект архитектурной, инженерной и строительной отраслей России. Данный объект, уже введенный в эксплуатацию и стал прецедентом реализации в России уникального по масштабу и сложности проекта в запланированные сроки и в рамках предусмотренного бюджета. Архитектурная доминанта «Лахта Центра» - башня высотой 462 метра - стала самым высоким зданием Европы. В настоящей статье рассматриваются следующие управленческие вызовы и решения: перенос объекта; ограничения участка и смежные проекты; необходимость разработки нормативной базы; отсутствие в России релевантного опыта и компетенций; выстраивание гибкой системы контрактования, разделение функций проектирования и СМР; гибкий подход в подготовке проектной документации, Главгосэкспертиза и начало нулевого цикла; этапы строительства; пакетное контрактование; управление глобальной командой; оптимизация проектных решений; система управления рисками; глобальный кризис; санкции; изменение роли заказчика/исполнителя в ходе реализации проекта.
\end{abstract}

Ключевые слова: высотное здание «Лахта Центр», строительные конструкции, управленческие вызовы и решения, уникальный строительный объект 


\section{GENERAL INFORMATION}

Lakhta Center is the headquarters of PJSC Gazprom, a key cultural and environmental project of St. Petersburg and the flagship object of the architectural, engineering and construction industries in Russia [1-9]. It is located on the coast of the Gulf of Finland and has become a forming element of the new marine facade of the city. In future, comfortable embankments and infrastructure facilities will be created around the object. Due to this, a new modern center of attraction is being created in the north of St. Petersburg.

The complex consists of five buildings and structures, the construction of which is divided into two phases. The first phase is 4 objects with an area of 400 thousand square meters and a construction volume of more than 2 million cubic meters. Second stage is an object with an area of 150 thousand square meters with a implementation period of 3.5 years: from 2017 to 2021.

The construction of the multifunctional complex Lakhta Center (first phase), which was begun in October 2012, had been completed in October 2018. The facility was completed for operating and became a precedent for the implementation of such a unique in scale and complexity project in Russia. It was realized on schedule and within the budget.

The architectural dominant of the Lakhta Center is a tower with a height of 462 meters, which has become the tallest building in Europe.

About 600 Russian and foreign companies and more than 20,000 people from 18 countries participated in the project.

The general contractor of the project is Renaissance Construction. The RMJM team under the direction of Tony Kettle developed the architectural concept of the Lakhta Center. CJSC Gorproekt developed the project. Samsung C\&T and CJSC Gorproekt (sub-designer) carried out detailed design.

\section{OBJECTS OF COMPLEX}

\subsection{Skyscraper.}

The aboveground part of the tower has 87 floors or 111 levels. At $360 \mathrm{~m}$, the highest observation deck in Europe is located.

The supertall spins around for 90 degrees from the base to the top, expanding and narrowing as you climb. The floors of the tower, metal structures and facade elements are not repeated.

\subsection{Multifunctional building.}

A multifunctional building is the horizontal dominant of the complex, that is of $260 \mathrm{~m}$ long with a variable number of floors from 7 to 17 ones.

In terms of complexity of architectural and structural elements, the multifunctional building is not inferior to the tower building: its height differs from 22 to 85 meters; there are interior widespan spaces, negative slopes of end facades.

The main pedestrian artery of the multifunctional building is the atrium, where the main public spaces of the Lakhta Center are concentrated: from a planetarium in the shape of a ball to a seven-story transformer hall.

\subsection{Arch of the main entrance.}

A separate building-entrance to the complex is a functionally unique solution that is made in the form of an asymmetric arch with a height difference from 18 to $24 \mathrm{~m}$. At the vanishing points of the axes, the arch span reaches 98 meters.

\subsection{Stylobate.}

Stylobate is a two-level underground parking of the complex. All buildings of the first stage of the Lakhta Center are located on a single stylobate, which runs almost to the borders of the development spot. The roof is exploitable. In the future, landscaping will be done at the top.

\subsection{Complex of buildings and structures.}

The object of the second stage of the Lakhta Center for the location of Gazprom Group offices reminiscents the multifunctional building both in architectural appearance and in design solutions. 


\section{MANAGEMENT CHALLENGES AND SOLUTIONS}

\subsection{Transfer of the object.}

The location of the facility in Lakhta is the result of a long dialogue with the conservative public of St. Petersburg. The initial concept of building of headquarters on the Okhtinsky cape, despite the obvious pluses for the development of the depressed Krasnogvardeisky district and the absence of a negative impact on the traditional postcard views of the city, was not accepted by the part of the urban urgency.

As a result, a location was determined. New location corresponded to the status of the project and was promising in terms of infrastructure development. The parameters of the site allowed significantly expanding the functionality of the project and making its architectural appearance more harmonious.

Overcoming the challenge was facilitated both by the fact of a bold and responsible decision to build an ambitious project in a conservative city, as well as by the unprecedented openness in its implementation, by effective non-standard information policy. As a result, the people unambiguously accepted the Lakhta Center project; it became a favorite attraction in the guise of a new futuristic ensemble on the coast.

\subsection{Land restrictions and related projects.}

The unique location of the building site in Lakhta on both sides limited by water and adjacent to the highway at the same time creates enormous difficulties at all stages. This is lacking of auxiliary sites for the deployment of construction camps, warehouses, heavy equipment, etc.; the need to synchronize plans and work with related projects (embankments, roads, and a yacht club), communication with city authorities on the timing of the introduction of engineering and road infrastructure.

Early planning and deep immersion in all the details of the organization of the construction process made it possible to prevent serious failures (for example, pouring the bottom plate of the box foundation [5] with coming of the concrete mixers on site every single minute).

In parallel, different types of work were carried out in each building. The next type of work started as soon as the site allowed and the documentation was ready. At peak moments, out by 12 thousand people simultaneously carried up to 3,000 types of work in a day. The work was carried out in three shifts 24/7. So, in 2017, building of core walls, installing columns, interfloor ceilings, facade glazing, laying engineering networks and architectural decoration went simultaneously at different levels of the tower.

In order to synchronize all types of work with the delivery of schedules up to minute plans, BIM technology was used. It allows you to visualize and synchronize schedules and logistics processes.

The construction of engineering infrastructure at the expense of the investor and solutions that were not obvious at first glance, for example, the construction of an autonomous gas boiler near the heating main, eliminated the dependence of the facility commissioning on third parties.

\subsection{The need to develop a regulatory docu- ments.}

At the time of the start of design, practically there were not regulatory documents for highrise and unique construction in Russia. So, for example, according to the "Technical Regulations for Fire Safety", all buildings above 50 meters are outside the regulation and should be designed according to specially developed Special Technical Condition (STU) with fire safety measures.

During the construction period, 3 "fire safety" STU for the Lakhta Center were issued. These documents covered totally about 20 points that were not regulated by standards.

There was also a need to develop and harmonize standards for new construction materials and technologies. In particular, it was necessary making a calculation proof, conducting tests and preparing STU to apply the composite structures in the tower (supporting perimeter columns). 
The same situation arose with fachwerk pillarcolumns made of laminated glass.

\subsection{Lack of relevant experience and compe- tencies in Russia.}

The unique architecture and innovative technologies have another side. They are practically absent in Russia, and relevant experience and competencies are significantly limited even in the world. Even if there are ready-made solutions in the world experience, their scale, as a rule, differs from Lakhta Center (width and depth of piles [4], foundation box structures, area of facades, energy-efficient glass compounding, etc.).

This created significant difficulties not only in the formation of the project team, but also in the selection of contractors. Not many companies were announced to participate in the tender, many of which "fell off" when studying technical tasks and getting to know the requirements for quality and deadlines.

However, this challenge was overcome. As a result, people gathered in the team, were ready to think outside the box, quickly make complex and responsible decisions, and treat the project as a personal challenge. The key partners of the project were chosen by a similar principle.

On the other hand, specialists with rare competencies that have not been in demand in Russia in recent decades have found application in the project and gained unique experience during its implementation.

3.5. Building a flexible contracting system. Separation of design and construction functions.

The factors described above did not allow the project management to shift the responsibility for the implementation of the project to the general designer / general contractor by concluding one or two contracts for the whole range of works. The "design and build" scheme, which required many months to prepare the requirements specification and contract, was unacceptable.
In particular, the project went through several iterations from the architectural concept to the Project stage, with the subsequent development of working documentation, which went for several stages ahead of the construction.

The construction part was organized in a similar way. At the initial stage, Arabtec was involved as a general contractor for the underground part, and then Renaissance was involved for executing of the rest of the complex of work with a package contracting strategy.

\subsection{A flexible approach to the preparation of project documentation. The main state ex- pertise (Glavgosekspertiza) and the begin- ning of the zero cycle.}

Project documentation was issued and approved by parts. The first projected object was the Lakhta Center tower. It passed the Glavgosexpertiza at the first time, which allowed us to begin work on the zero cycle (building a wall in the ground and creating a pile field under the box foundation of the future skyscraper). An early start of the zero-cycle construction and installation work was executed before the selection of the main general contractor, which the subsequently accept responsibility for previously completed work.

In parallel with the construction work, a package of documents was developed for the remaining facilities of the complex: Multifunctional building, Arch and Stylobate, after which the entire project was once again reviewed by the Main State Expertise (Glavgosekspertiza). Totally, there were six such examinations when adjustments were made or the degree of optimization and detailing of the Project increased. Therefore, for example, fachwerk pillar-columns made of laminated heat-strengthened glass, originally envisaged by the project, appeared in the Arch. However due to the lack of a regulatory base, it took time to develop requirements for such structures and include them in special technical specifications, conduct a series of tests for column specimens, develop a methodology of their calculation before defending the design decision in Glavgosekspertiza of Russia. 


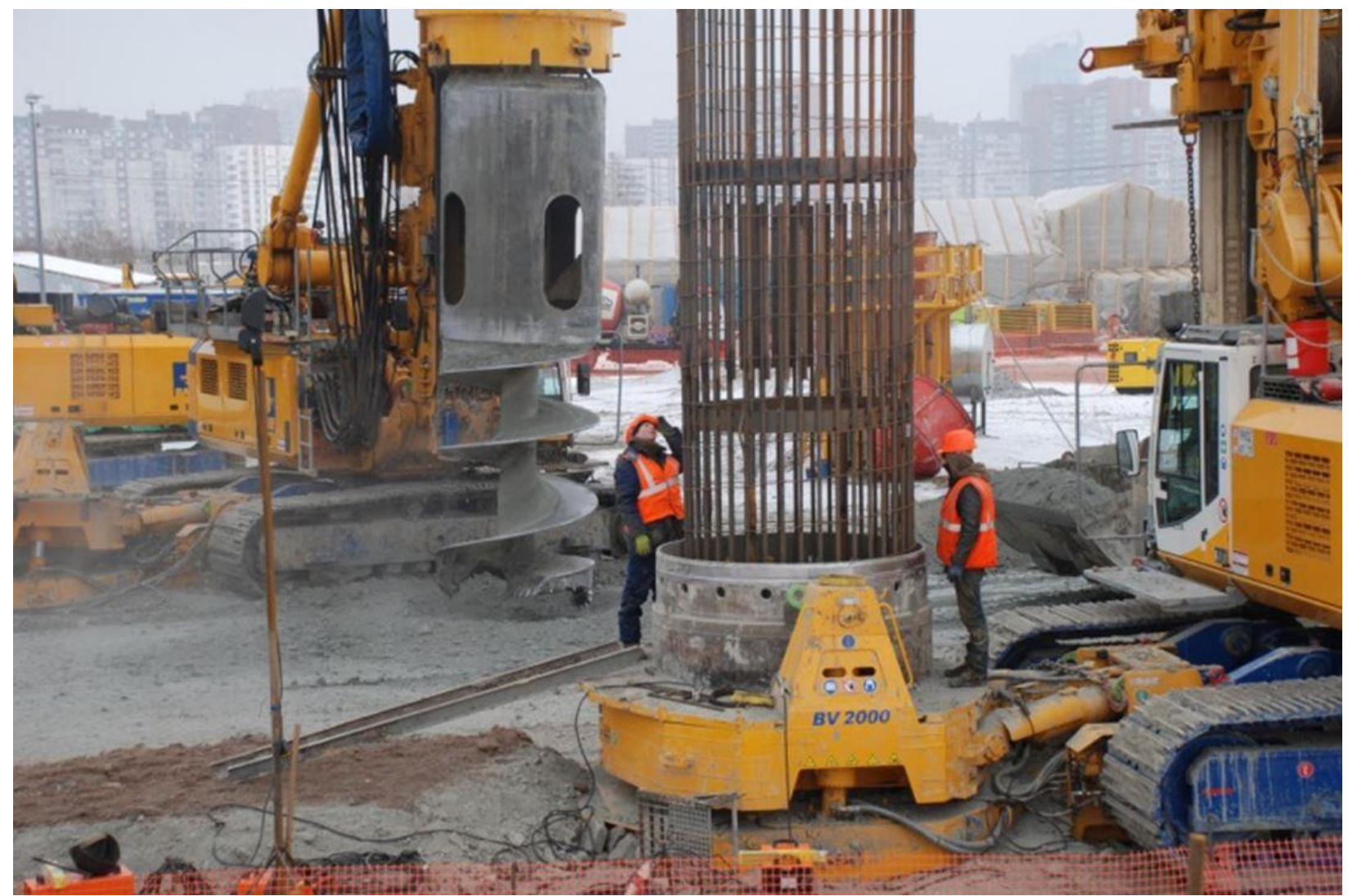

Figure 1. Installation of the frame of the bored pile.

Such a differentiated approach to coordination in the conditions of tight deadlines for the construction of the facility made it possible efficiently using the team's resources and to proceed as quickly as possible to the implementation of the project.

\subsection{Building stages.}

The construction of the Lakhta Center tower was launched in October 2012. At first, builders made 264 piles with a diameter of 2 meters with a length of 55 and 65 meters from ground level (or 72 and 82 meters, if we counted from the level of the surface of the earth). Then the foundation pit was fenced using the "wall in soil" and monolithic reinforced concrete disks around the perimeter using the "Semi-top-down" method.

In accordance with the design solution of the foundation, it was necessary to build a foundation pit with a depth of $18 \mathrm{~m}$ in the conditions of weak soils of St. Petersburg for placing the box foundation in the form of a pentagon inscribed in a circle with a diameter of $100 \mathrm{~m}$.
Taking account the high level of groundwater, a wall in the ground, entering the Vendian clay, was chosen as the fence of the pit. In order to select a spacer structure, more than 10 variants were considered, including using anchor fasteners. The variant in the form of temporary 4 disk floor slabs of $600 \mathrm{~mm}$ thick in the form of a ring of minimum width of about $9 \mathrm{~m}$ was chosen as a result of the technical and economic comparison of the variants. The final variant of the enclosing and holding structures of the pit is shown in Figures 2, 3.

The next important stage was the construction of the box foundation structures, which includes two underground floors of the tower. The total volume of concrete in the box foundation is $46,000 \mathrm{~m}^{3}$. The volume of concrete in the bottom slab of the box foundation with a thickness of 3.6 meters was $19,624 \mathrm{~m}^{3}$.

In order to increase the reliability of the foundation, it was decided concreting the bottom plate of the box foundation without a time break, that avoided the installation of technological joints, which are additional stress concentrators. 


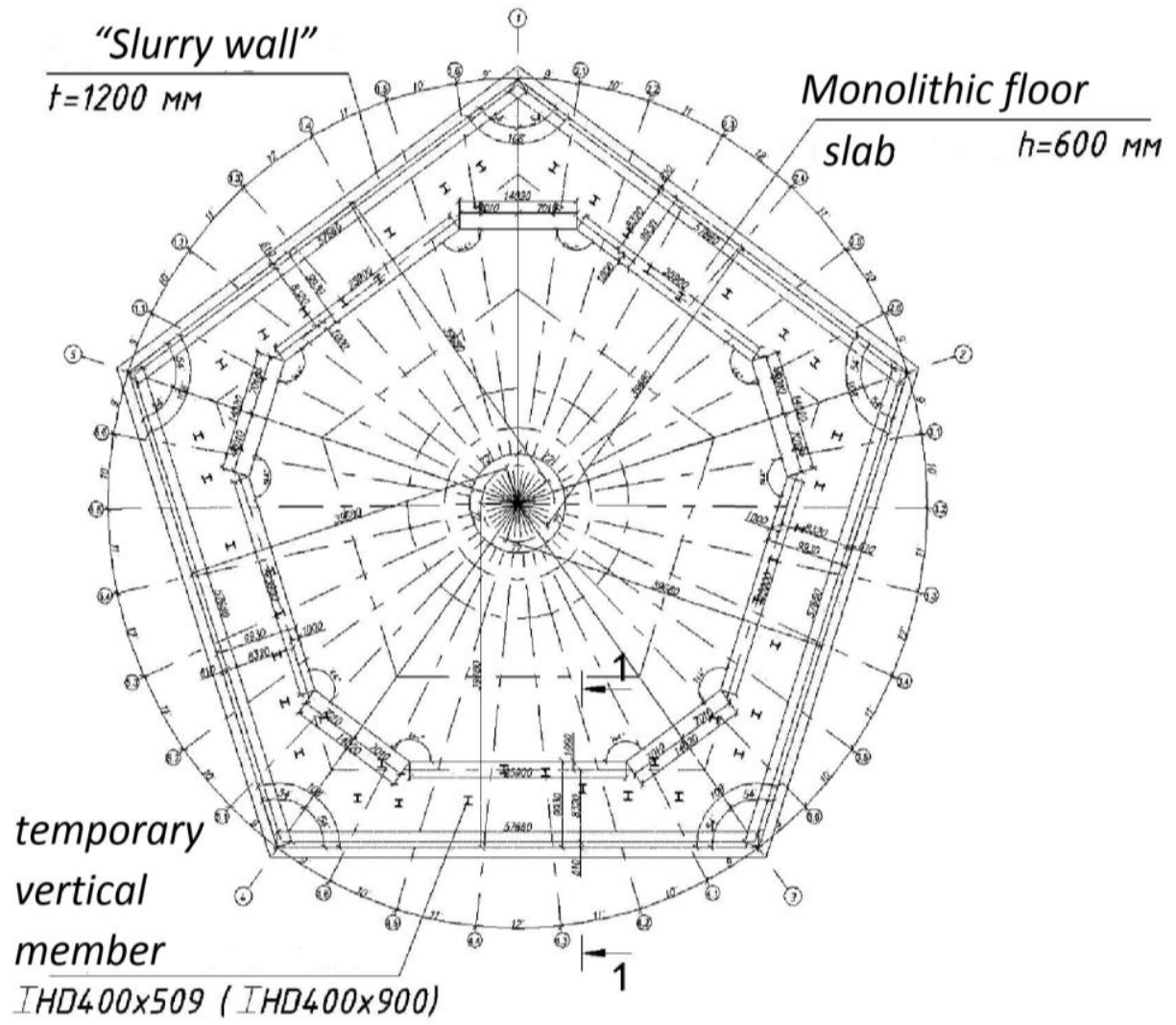

Figure 2. Plan of foundation pit fence for building of the tower.

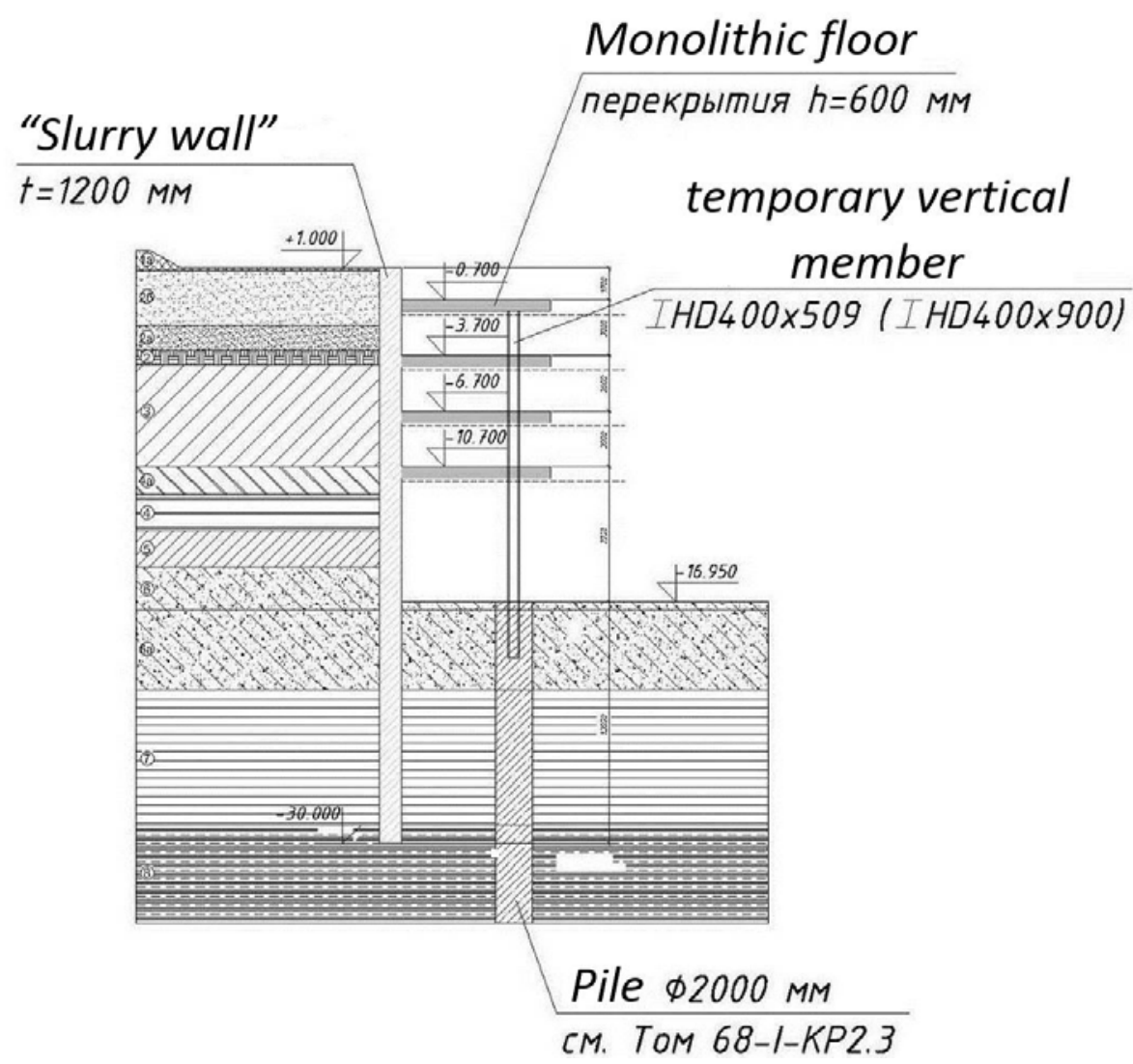

Figure 3. Section of the structure of the foundation pit fence for building of the tower. 


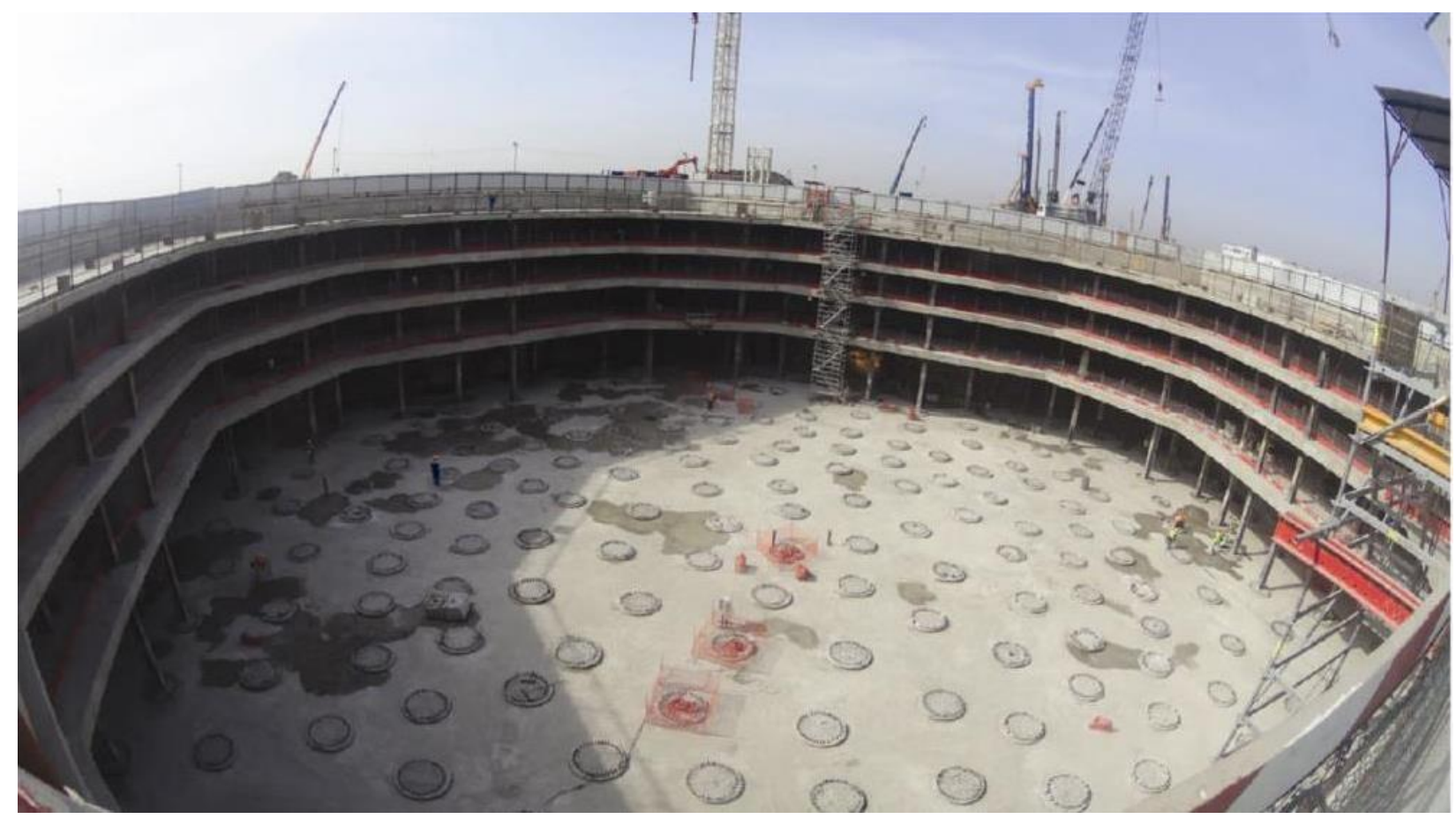

Figure 4. General view of the pit after excavation until design mark and preparation for concreting.

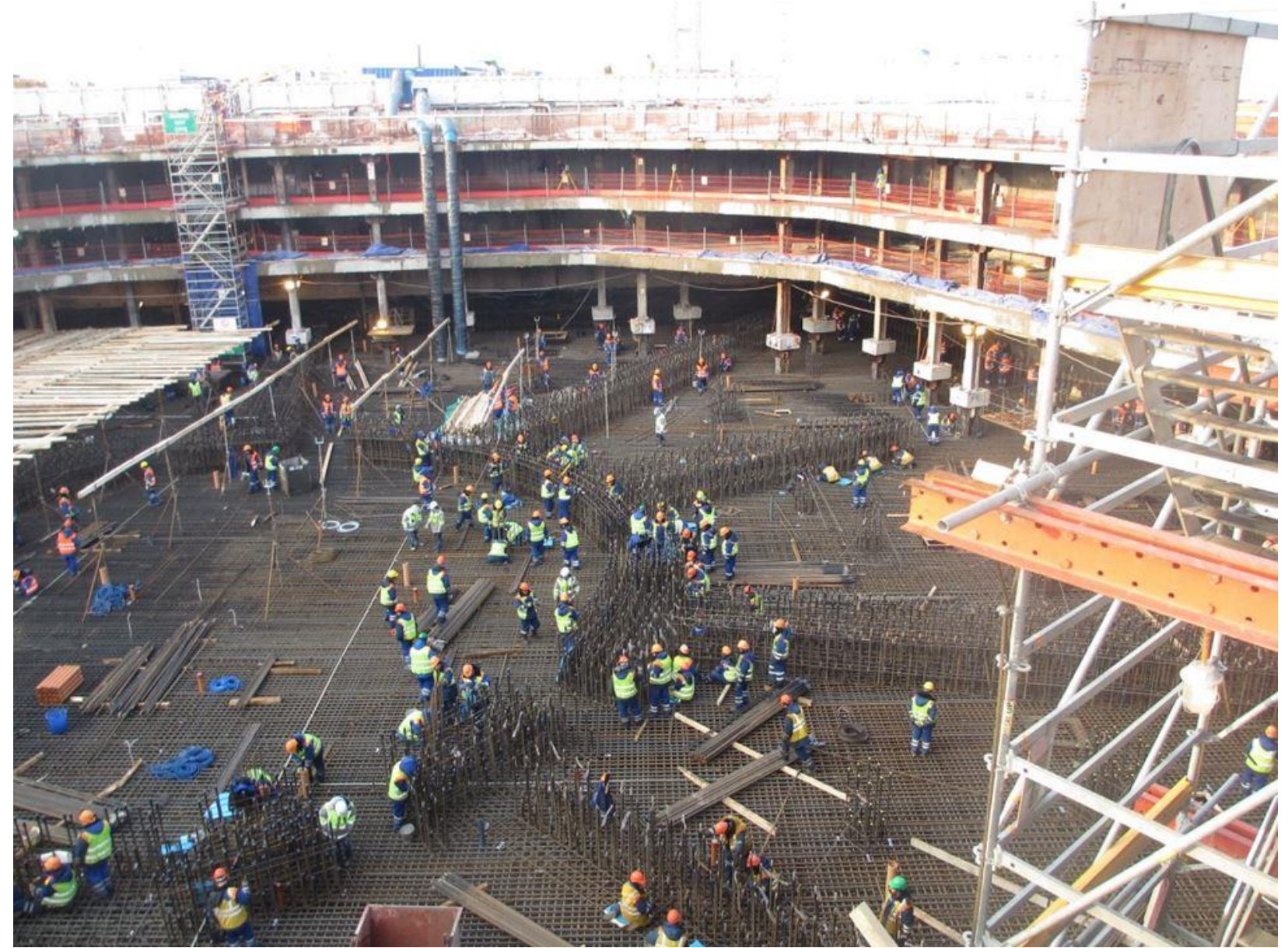

Figure 5. Reinforcement of the bottom plate of the box foundation. 


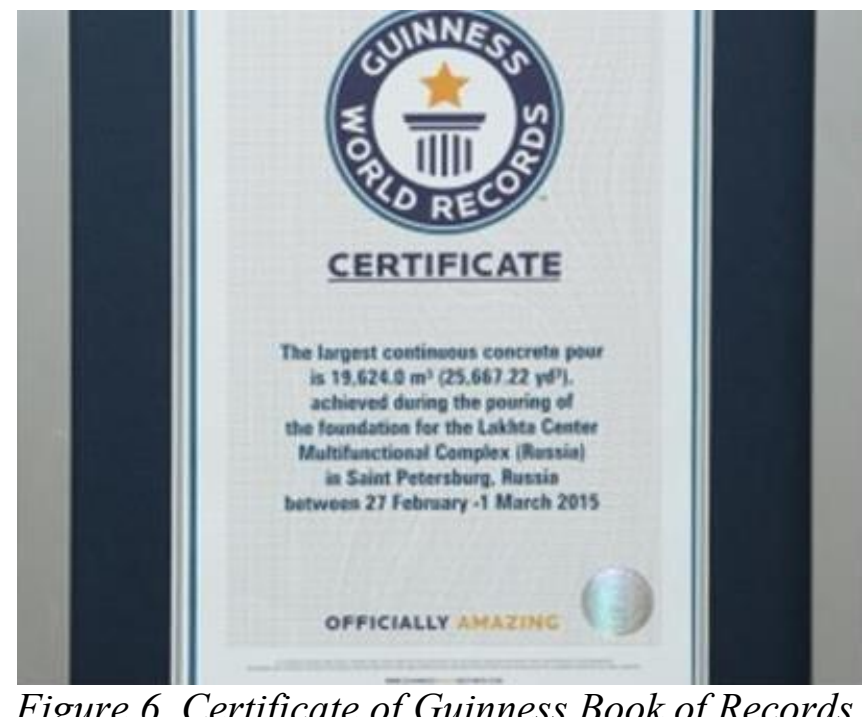

For this purpose, all reinforcement of the slab was previously connected in the foundation pit and the composition of special self-compacting concrete was developed. 18 points of concrete reception were organized on the edge of the foundation pit. 13 concrete working plants with an interval of 1-1.5 minutes delivered concrete. As a result, the bottom slab was concreted in 49.2 hours, and thereby it set the world record for continuous concreting, as recorded in the Guinness Book of Records.

In order to reduce the exothermy of concrete of class B60, it was stipulated that concrete mixtures should have a low energy potential and have a Portland cement consumption of not more than $360 \mathrm{~kg} / \mathrm{m} 3$ in terms of clinker with a trialuminate content of not more than $8 \%$. Concrete mixtures delivered to the construction site should have temperature in the range $+5 \ldots+15$ $\circ$ C. The densely reinforced structure of the lower foundation slab was concreted using a self-compacting concrete mixture with a mobility in the range from 60 to $65 \mathrm{~cm}$. Particular attention was paid to the temperature regime when concrete mixture set the strength. Concrete should have minimal exotherm and hardening kinetics at an early age under normal temperature and humidity conditions. At the same time, the required compressive strength of concrete at least 1 day old is $0 \mathrm{MPa}$, at least 3 days old is $15 \mathrm{MPa}$, at least 7 days old is 40
$\mathrm{MPa}$, and at least 28 days old is $65 \mathrm{MPa}$. The aging of concrete in the structure was carried out under conditions that prevent thermal shrinkage with the cooling rate of concrete in the core of the slab not more than $2.0-3.0^{\circ} \mathrm{C}$ per day and the temperature difference between zones having a common border height of the slab of not more than $20^{\circ} \mathrm{C}$.

The concrete mixture was prepared according to the standard technological scheme taking into account the requirements of GOST 7473-2010 on the accuracy of dosing of materials and the features associated with the order of loading and mixing the main components of the mixture and powder additives. It was carried out in two stages: the stage of dosing, loading and mixing the components in a stationary concrete plant mixer; mixing stage in a concrete mixer during the transportation of mixtures to the construction site.

Builders mounted a protective tent in order to protect against atmospheric precipitation and ensure regulated requirements for the temperature regime of concrete curing, as well as for the comfortable organization of work on the entire front of concreting of the slab structure and to provide required temperature regime of heating the air under the tent.

Heat generators with adjustable power were used to control the temperature regime. 


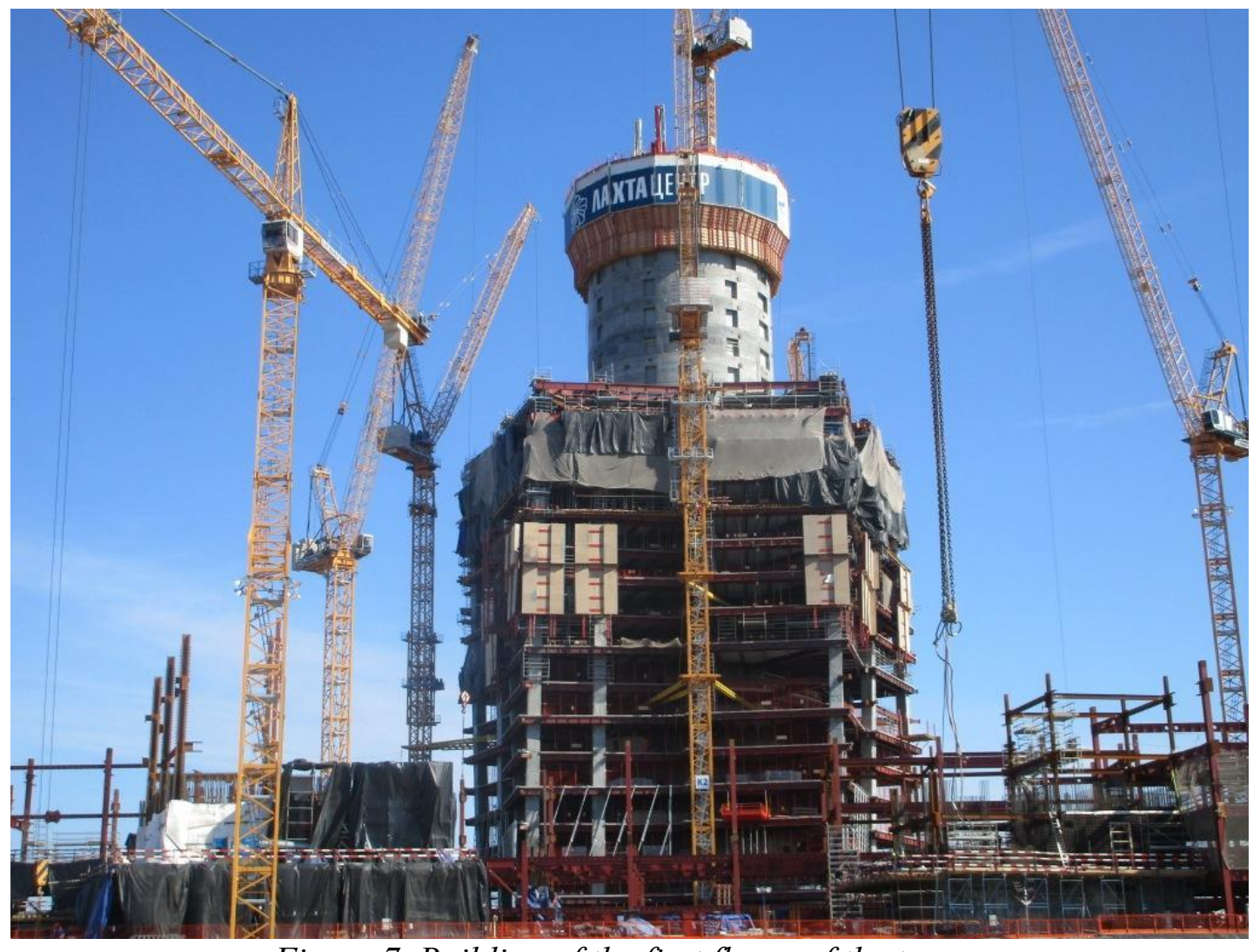

Figure 7. Building of the first floors of the tower.

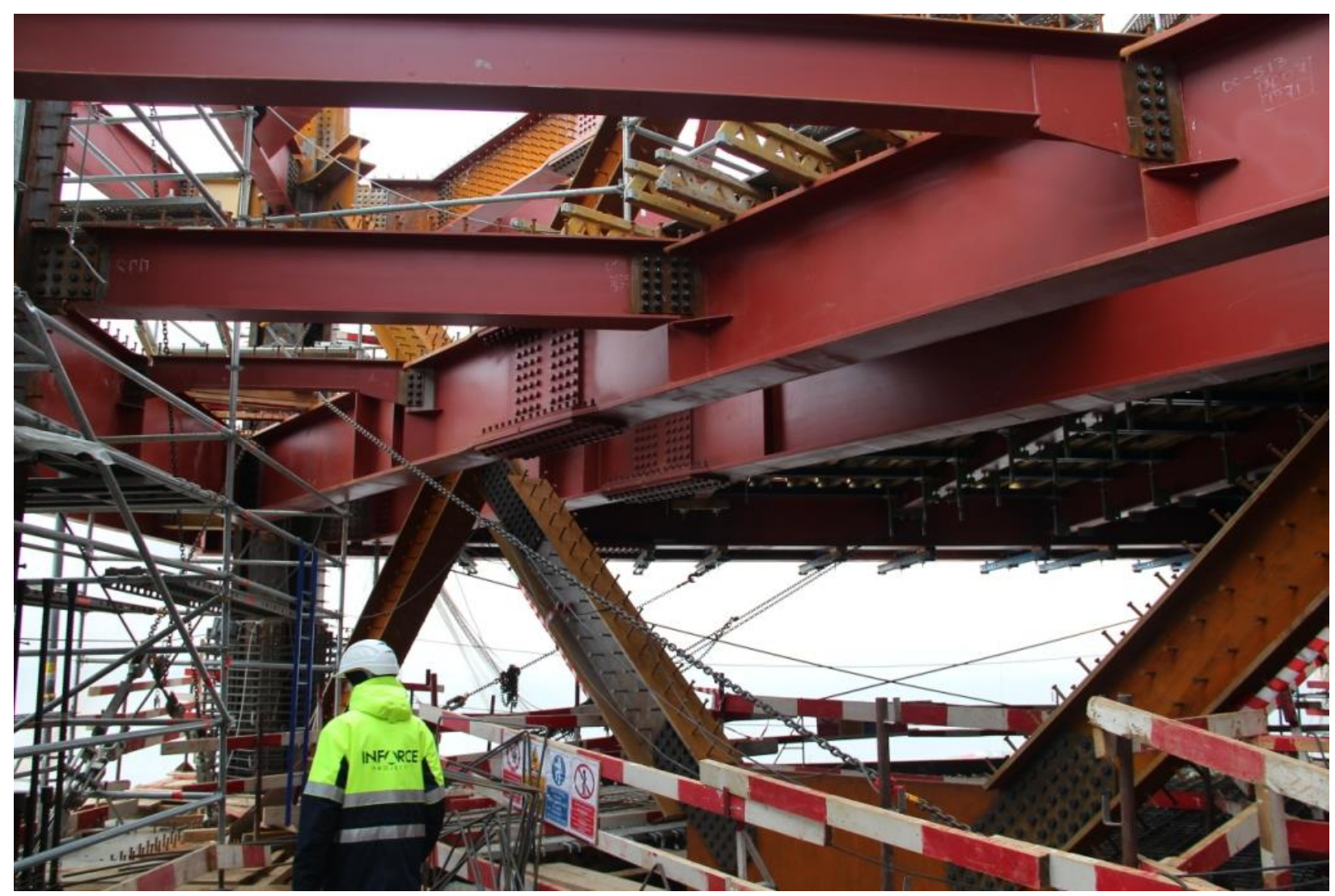

Figure 8. Building of metal structures of outrigger level. 


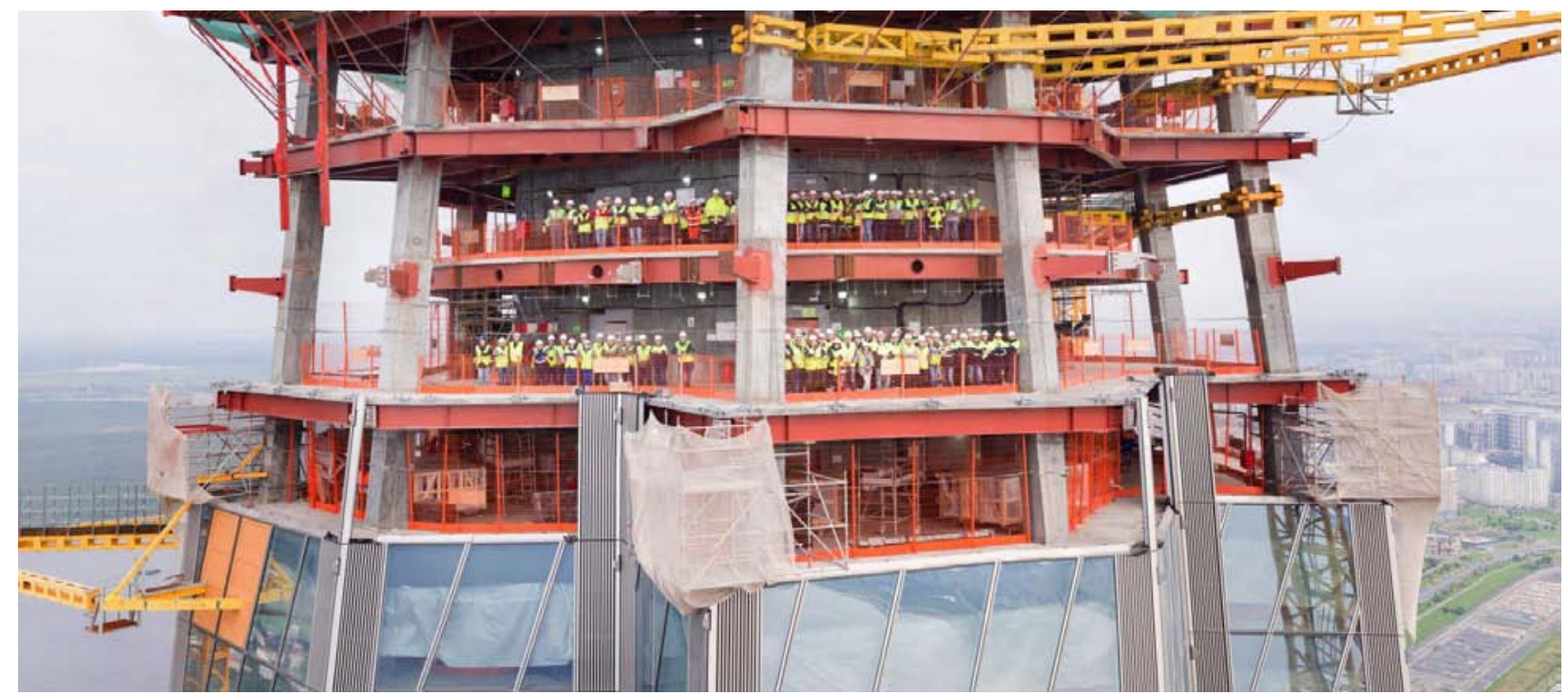

Figure 9. Overlaps.

The temperature control of the hardening of concrete in the lower foundation slab was carried out using an automated system based on the use of temperature sensors. Such sensors were installed in different zones of the concrete slab: in the core and on the periphery of the structure at three elevations, as well as in the upper zone of the slab in areas where are the walls of the box foundation.

During the construction of the aboveground part of the tower, advanced construction technologies were actively used. Initially, the reinforced concrete central core of the tower was made in average of 5-7 floors ahead of the other underlying structures. Then there was the installation of metal structures of the cores of steel-reinforced concrete columns [6-9], metal beams of floors. The final step of this technology for the construction of tower structures was the concreting of steel-reinforced concrete columns and floor slabs.

The spire of the tower with a height of 118 meters began to be mounted from the level of 83 floors at height mark 344,400 . The top of the spire is located at height mark 462 meters. The installation of the spire was completed in early 2018 .

The construction of the Lakhta Center skyscraper was launched in October 2012 and completed in 2018.

Key achivements are specified below.
- A world record fixed in the Guinness Book of Records was set. On March 1, 2015, a 49hour non-stop pouring of concrete was completed. $19624 \mathrm{~m} 3$ of concrete were laid in the bottom plate of the box foundation of the Lakhta Center tower.

- The Lakhta Center Tower has become the northernmost skyscraper in the world.

- For the first time, a Russian skyscraper received an international green certificate of the highest level - LEED Platinum.

- The largest volume of scientific support in the construction of civil buildings in Russia. Only at the zero cycle, 13 institutes and companies were involved.

- A world-class project gave an impetus to the development of the Russian construction industry in terms of developing a new regulatory documents for high-rise and unique construction.

- More than 100 technological innovations were applied, among which:

- The first in civil engineering applied composite supporting columns made of steelreinforced concrete. The decision reduced the construction time of columns by $40 \%$ while reducing their cost by almost half.

- Implemented one of the largest volumes of facade glazing in the world - 130 thousand square meters of cold-formed glass. 


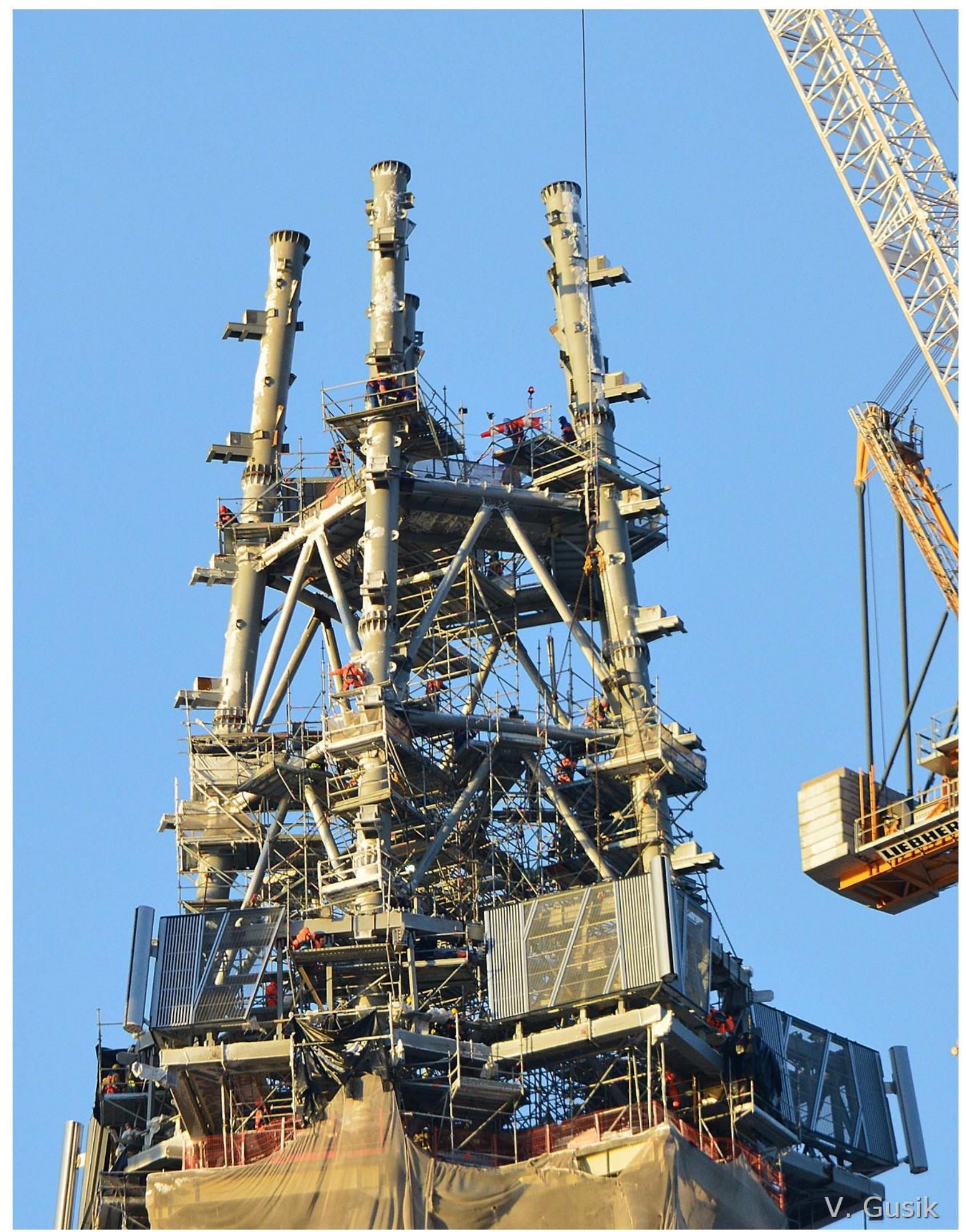

Figure 10. Mounting the spire. 


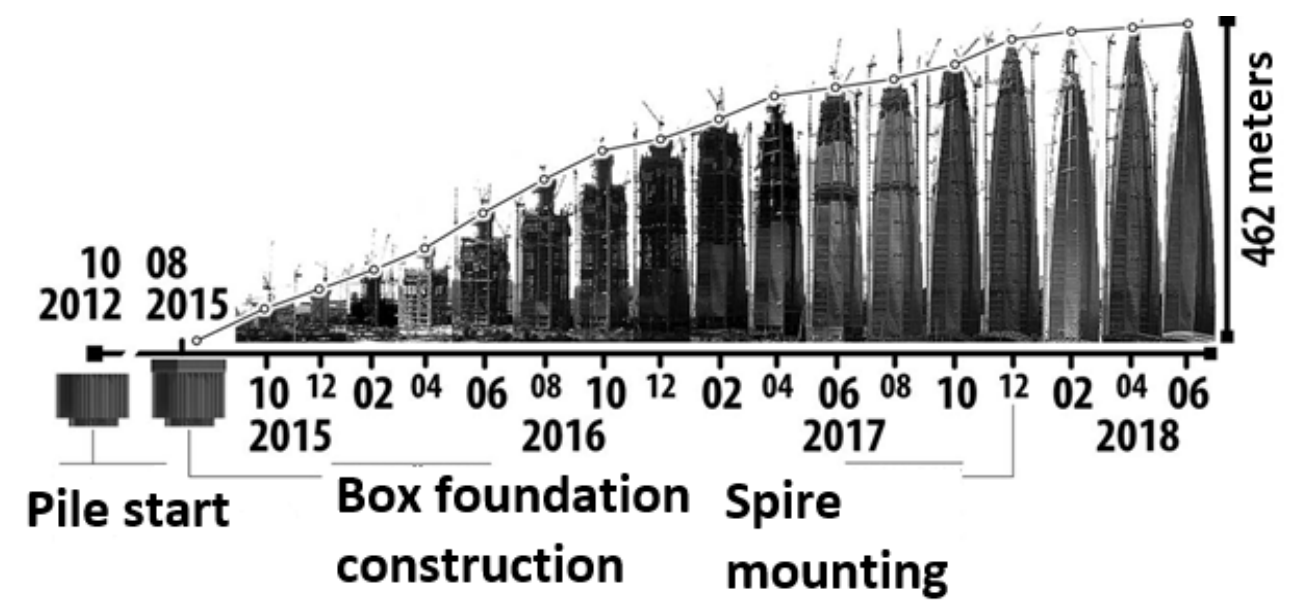

Figure 11. Building stages.

- For the first time in Russia, experience was gained in the construction of high-rise buildings on Vendian clay. About $40 \mathrm{~km}$ of exploratory wells were drilled until depth of $150 \mathrm{~m}$ on the Lakhta Center site; a scientific and practical base has been created for use in construction in Northwest Russia.

- Innovative techniques in the construction of a high-rise building made it possible to ensure absolute verticality. The maximum deviation during the construction of the core is up to $6 \mathrm{~mm}$.

- A unique Russian development of a system for monitoring structural deformations, which in real time monitors the complex components according to hundreds of indicators $[2,3]$.

\subsection{Package contracting system.}

Lakhta Center specialists created their own package contracting system, which allowed not only staying within the budget, but also save up to $19 \%$ of the initial project budget at some stages. The essence of the approach is to divide the upcoming work front into large packages, the cost of which was calculated only after the appearance of working documentation. This allows us to determine the cost of the final list of works, taking into account real costs. With the traditional approach, such a cost would inevitably be approximate and overpriced. Such a strategy made it possible to reduce the terms of release and improve the quality of work due to cross-control between performers.

\subsection{Managing by the global team.}

Attracting the best world experience, the most experienced specialists and creating a competitive environment within the team by dividing the functions between large partners led to a unique result that is the creation of a huge global team. 18 countries, more than 600 companies and 20,000 people at the site became a challenge for the project management. The managing team of Russian specialists consists of 100 people in total.

Mental and cultural differences, language barriers as a result did not put to achieve the goal. On the contrary, the project strengthened the image as the global, gained international recognition in professional circles. This largely happened due to:

- flexibility in negotiations and the ability to interest potential partners in achieving the goal on mutually beneficial conditions;

- strategies for jointly with the construction manager and / or general contractor choosing contractors, attracting a wide range of contractors and suppliers, both foreign and Russian;

- the creation of a universal, flexible and mobile team of the Customer consisting of young, ambitious and highly qualified specialists, capable of solving issues of any complexity in all areas of activity (technical, financial, legal, administrative, commercial, communication and etc.); 
- placing the Customer's team on the project site and direct interaction of the Customer with partners;

- deep involvement of the Customer team in the development of design and design solutions;

- the interest of all participants of the global team to implement non-standard tasks and advanced architectural and technological solutions;

- a flexible management system with a staff structure that varies depending on the stage of the project, the targeted involvement of leading experts and consultants.

\subsection{Optimization of the project solutions.}

A number of decisions were accepted that made it possible to maintain and even improve the quality of the project while reducing costs. So, the originally planned anchor spacer system was replaced with a disk spacer system, which significantly reduced the main costs and allowed to shorten the output period for the preparatory cycle of the Multifunctional building. The technology of glass supporting columns, successfully implemented in the facades of the multifunctional building, was subsequently applied on the facades of the arch, which is the main entrance to the complex. That makes the structure lighter and more transparent. Thanks to the optimization of engineering solutions, even in the smallest details, it was possible to achieve excellent indicators, for example, in water efficiency, which made it possible to achieve LEED Platinum.

\subsection{Risk management system}

Throughout the project implementation period, the project management team built a strategy and applied a risk management system. The risks included global country risks, including international sanctions; bankruptcy risk of large companies; risks of default on the part of related government agencies; risks of making significant changes to the project at the implementation stage and much more, up to the risks of small incidents during construction and weather conditions. In total, this is several thousand points.

Systematization, early diagnosis of the problems of contractors and suppliers, indifferent participation in resolving all issues up to going to production and offering technology and logistics allowed us to avoid significant delays even at certain stages, and in case of risks, allowed make changes to the sequence of work so that all resources are used as efficiently as possible.

\subsection{Global crisis.}

During the period from 2012 to 2018, there were a number of geopolitical shocks and a related currency crisis (2014-2015). This would seem that an increase in the costs of the project to be inevitable due to the revaluation of the cost of imported materials and services of foreign specialists. However, thanks to a nontrivial approach to the contracting process, agreements were reached with most counterparties on the separation of the ruble and currency components.

It was localized a number of foreign industries from the Italian Chimolai to the German Gartner, which allowed to reduce the long-term costs of the manufacturer and maintain the necessary level of product prices. Another resource is the use of domestic materials. Metal structures excepting the column cores, reinforcement, concrete and some other materials are completely Russian-made with the costs of the products in ruble value. In relation to hard currencies, such materials became cheaper and this offset the increase in costs of imported products. The situation with the cost of services is similar.

\subsection{Sanctions.}

The imposition of sanctions was a serious blow for many companies in a wide variety of industries working with foreign counterparties. In the case of Lakhta Center, this risk was not realized and did not affect the timing and cost of the facility. Global companies participated in the project in the form of their Russian divisions. For some, the condition for participation in the project was the localization of production. In addi- 
tion, ceteris paribus during the competitive procedures, preference was given to Russian contractors and suppliers (metal structures).

Political risks during exacerbation of relations between the countries were offset by the presence of previously concluded contracts for all types of work.

\subsection{Changing the role of the customer / con- tractor during the project.}

Flexibility and adaptability allowed the project team to fulfill all the obligations and implement the project within the stated time, while maintaining the basic functionality and concept.

Therefore, the role of the Customer in the project has repeatedly changed. We acted as a developer realizing the task set by the Investor, as a management company that will operate the building, manage the leased space and represent the functional and program part of the project to the management company. Today, the company acts as a Seller, conducting the procedure of transferring the object to the new owner and as an Agent, completing a number of finishing work on the initiative of the owner.

However, as a result, despite the changing interaction format, the complex was put into operation and received an act of conformity with the project. In addition, a full-scale transfer to the owner is underway for subsequent operation.

\section{REFERENCES}

1. Ilyukhina E.A., Lahman S.I., Miller A.B., Travush V.I. Konstruktivnye reshenija vysotnogo zdanija «Lahta Centr» v SanktPeterburge [Design Solutions of the HighRise Building "Lakhta Center" in SaintPetersburg]. // Academia. Arkhitektura $i$ stroitel'stvo, 2019, No. 3, pp. 110-121 (in Russian).

2. Travush V.I., Shulyatev O.A., Shulyatev S.O., Shahramanyan A.M., Kolotovichev Yu.A. Analiz rezul'tatov geotehnicheskogo monitoringa bashni "Lahta Centr" [Analysis of the results of geotechnical monitoring of the tower "Lakhta Center"]. // Osnovani$j a$, fundamenty $i$ mehanika gruntov, 2019, No. 2, pp. 15-21 (in Russian).

3. Travush V.I., Shakhraman'yan A.M., Kolotovichev YU.A., Shakhvorostov A.I., Desyatkin M.V., Shulyat'yev O.A., Shulyat'yev S.O. "Lakhta tsentr" avtomatizirovannyy monitoring deformatsiy nesushchikh konstruktsiy i osnovaniya [Lakhta Center automated monitoring of deformations of load-bearing structures and foundations]. // Academia. Arkhitektura $i$ stroitel'stvo, 2018, No. 4, pp. 94-108 (in Russian).

4. Travush V.I., Shulyatev S.O. Adjusted pile foundation construction for skyscrapers. // IOP Conference Series: Materials Science and Engineering, 2018, Volume 456, conference 1, 012008 .

5. Travush V.I., Shakhvorostov A.I. Betonirovaniye nizhney plity korobchatogo fundamenta kompleksa "Lakhta tsentr" [Concreting of the bottom slab of the box-shaped foundation of the Lakhta Center complex]. // Vysotnyye zdaniya, 2015, No. 1, pp. 92101 (in Russian).

6. Travush V.I., Konin D.V., Rozhkova L.S., Krylov A.S., Kaprielov S.S., Chilin I.A., Martirosyan A.S., Fimkin A.I. Eksperimental'nyye issledovaniya stalezhelezobetonnykh konstruktsiy na vnetsentrennoye szhatiye [Experimental studies of steel-reinforced concrete structures for eccentric compression]. // Academia. Arkhitektura i stroitel'stvo, 2016, No 3, pp.127-135 (in Russian).

7. Travush V.I., Konin D.V., Kaprielov S.S., Konin D.V., Krylov A.S., Chilin I.A. Jeksperimental'nye issledovanija stalezhelezobetonnyh konstrukcij, rabotajushhih na izgib [Experimental studies of steelreinforced concrete structures working on bending]. // Stroitel'stvo i rekonstrukcija, 2017, No. 4(72), pp. 63-71 (in Russian).

8. Travush V.I., Kashevarova G.G., Martirosyan A.S. Computer modelling as evaluation method of column base bearing ca- 
pacity in tower building. // Procedia Engineering, 2016, Vol. 153, pp. 773-780.

9. Travush V.I., Kashevarova G.G., Martirosyan A.S., Avhacheva I.A. Experimental study of possible ways to increase cohesion strength in the "steel - concrete" contact zone under displacement conditions. // Procedia Engineering, 2016, Vol. 153, pp. 766-772.

\section{СПИСОК ЛИТЕРАТУРЫ}

1. Илюхина Е.А., Лахман С.И., Миллер А.Б., Травуш В.И. Конструктивные решения высотного здания «Лахта центр» в Санкт-Петербурге. // Academia. Apхитектура и строительство, 2019, №3, с. 110-121.

2. Травуш В.И., Шулятьев О.А., Шулятьев С.О., Шахраманьян А.М., Колотовичев Ю.А. Анализ результатов геотехнического мониторинга башни «Лахта Центр». // Основания, фундаменты и механика грунтов, 2019, №2, с. 15-21.

3. Травуш В.И., Шахраманьян А.М., Колотовичев Ю.А., Шахворостов А.И.. Десяткин М.В., Шулятьев О.А., Шулятьев С.О. «Лахта центр» автоматизированный мониторинг деформаций несущих конструкций и основания. // Acadeтіа. Архитектура и строительство, 2018, №4, c. 94-108.

4. Travush V.I., Shulyatev S.O. Adjusted pile foundation construction for skyscrapers. // IOP Conference Series: Materials Science and Engineering, 2018, Volume 456, conference 1, 012008 .

5. Травуш В.И., Шахворостов А.И. Бетонирование нижней плиты коробчатого фундамента комплекса «Лахта центр». // Bысотные здания, 2015, №1, с. 92-101.

6. Травуш В.И., Конин Д.В., Рожкова Л.С., Крылов А.С., Каприелов С.С., Чилин И.А., Мартиросян А.С., Фимкин А.И. Экспериментальные исследования сталежелезобетонных конструк- ций на внецентренное сжатие. // Academia. Архитектура и строительство, 2016, №3, c. 127-135.

7. Травуш В.И., Каприелов С.С., Конин Д.В., Крылов А.С., Чилин И.А. Экспериментальные исследования сталежелезобетонных конструкций, работающих на изгиб. // Строительство и реконструкиия, 2017, №4(72), с. 63-71.

8. Travush V.I., Kashevarova G.G., Martirosyan A.S. Computer modelling as evaluation method of column base bearing capacity in tower building. // Procedia Engineering, 2016, Vol. 153, pp. 773-780.

9. Travush V.I., Kashevarova G.G., Martirosyan A.S., Avhacheva I.A. Experimental study of possible ways to increase cohesion strength in the "steel - concrete" contact zone under displacement conditions. // Procedia Engineering, 2016, Vol. 153, pp. 766-772.

Илюхина Елена Анатольевна, кандидат экономических наук; генеральный директор, Акционерное общество «Многофункциональный комплекс «Лахта центр»; 190000, Россия, г. Санкт-Петербург, ул. Почтамтская, д. 3-5, литер «А», ч.пом. $1 \mathrm{H}$, ком. 370 ; тел. +7 (800) 700-31-52.

Миллер Алексей Борисович, кандидат экономических наук; председатель правления, публичное акционерное общество «Газпром»; 117997, Россия, ГСП-7, г. Москва, ул. Наметкина, д. 16; тел. +7 (495) 719-21-09; факсы: +7(495) 719-83-33, +7(812) 413-73-33;

E-mail: gazprom@gazprom.ru.

Elena A. Ilyukhina, Ph.D., General Director, Joint Stock Company "Multifunctional complex Lakhta Center"; 3-5, ul. Pochtamtskaya, Saint-Petersburg, 190000, Russia; phone: +7(800) 700-31-52.

Alexey B. Miller, Ph.D., Chairman of the Management Committee of public joint stock company "Gazprom"; 16, ul. Nametkina, Moscow, 117997, Russia; fax: +7(495) 719-83-33,+7(812) 413-73-33; E-mail: gazprom@gazprom.ru. 